\title{
CAPACITY BUILDING OF FISH PROCESSING BUSINESS GROUP BY SINJAI REGENCY FIHSERIES SERVICE SOUTH SULAWESI, INDONESIA
}

\author{
Muhammad Yunus, Akmal Ibrahim, Syamsiah Hasyim \\ Faculty of Social and Political Sciences, University of Hasanuddin
}

INDONESIA

Corresponding Author Email: myunus59@yahoo.com

\begin{abstract}
This study aims to find out and analyze the process of implementing capacity building for fish processing business groups by the Fisheries Service in Sinjai District. Data collection in this study is through interviews, and documentation. Data were analyzed using qualitative analysis. The results showed that in the process of implementing capacity building for fish business groups through training carried out by the Sinjai Regency Fisheries Office it had ineffective. There are several obstacles faced in the effort to develop the capacity of fish business groups, among others: Development participants have an unequal or heterogeneous background, such as education, work experience, and age. This will complicate and hamper the smoothness and implementation of training and education because of their catching power, perceptions, and reasoning for the lessons given differently. The curriculum that is established and taught is not in accordance with the needs of the trainees, in addition to the duration of the material delivery time is very short. In addition, the continuation of coaching is still lacking because after the training, it is not followed up by providing business capital as one of the problems faced by the group.
\end{abstract}

Keywords : Capacity Building, Fish Processing Group

\section{INTRODUCTION}

Indonesia is a country with coastal and ocean that extends approximately $81,000 \mathrm{~km}$ of coastline and spread to about 17,508 with about 8.5 million $\mathrm{km} 2$ of territorial waters including the Exclusive Economic Zone of Indonesia (ZEEI), has the potential of biological resources are abundant and diverse kinds. These resources have important value both the domestic and international market coast. Where the socio-economic component of most of Indonesia's population (approximately 60\%) live coastal areas (with an average growth of $2 \%$ per year). This is because administratively, most of the districts and cities are located in coastal areas. Based on the sub-district of the 4,028 districts there are 1,129 districts in terms of topography located in coastal areas, and from 62472 villages there are about 5479 villages are the coastal villages (Susanti, 2015).

From the data obtained from the Department of Fishery showed that from 2013 to 2016 the number of fishery management groups there are 52 business groups. Of these, the least is the management through fish processing that is only 9 business groups from 3 
District, North Sinjai District, East Sinjai District and Sembilan Island Sub-district. This is influenced by several inhibiting factors faced in the field. And from the results of the last 3 years Accountability Report shows that the labor force in the field of processing and marketing of fishery products as many as 1,409 people with the largest contribution to the workforce of retailers.

The existing obstacles are the lack of available processing facilities and infrastructure and the available technical guidance and training which are limited. In addition, the available human resources are still limited to the experience undertaken in the course of the implementation of processing activities. The lack of technology management of the production is also one of the barriers in the process of increasing the fishery product. From some activities that have been done. Achievement of the target until the current year by conducting training and technical guidance on the processing group only with a target achievement of $30 \%$ with a target of 50\% per year. (Accountability report 2015 Fishery Department Sinjai Regency).

\section{THEORETICAL STUDY}

Basically every focused activity must have clear goals, containing the results to be achieved in carrying out the activity. Similarly with the development program. The outcomes to be achieved should be formulated clearly so that the steps of preparation and implementation of the program can be devoted to achieving the targets set. Clearly formulated objectives will serve as an important reference in determining the material to be provided, the means and objectives required. Better non-specific or overly targeted goals will hinder the preparation and execution of activities so as to address development needs. Human Resource Management is the function within an organization that focused on recruitment of, management of, and providing direction for the people who work in the organization. It is also a strategic and comprehensive approach of managing people and the work place culture and environment (Susan in P.V.C. Okoye and Raymond A. Ezejiofor, 2013)

Human resource development through training is a concept in providing teaching in addition and knowledge, skills and attitude changes (Sedarmayanti, 2016). Rivai (2005), divides the four stages of the training implementation process: Needs Assessment, Training Objectives, Program Content, Learning Principles. Furthermore, there are two concepts of training according to Rivai et al (2014), as follows: (1) Training is the process of systematically changing the behavior of employees to achieve organizational goals. Training deals with the skills and abilities of employees to carry out current work. Training has a current orientation and helps employees to achieve certain skills and abilities to succeed in carrying out their work; (2) a formal training program is an employment undertaking to provide an employee with the opportunity to obtain a job or a field of work appropriate to his or her abilities, attitudes, and knowledge. The tools developed to more easily provide survival needs, the natural skills and abilities of human labor became exposed resulting in a natural division of skill crafts, such as carpentry and weaving (Rahman, Nicole , 2015).

\section{RESEARCH METHODS}

Training activities are basically implemented to generate behavioral changes from the people who attend the training. The change of behavior mentioned here can be the increase of knowledge, skills, ability, and attitude and behavior changes (Rivai et al, 2014). This study examines the process of implementing the development through training in the fish processing group that has been implemented by the Fishery Department of Sinjai Regency 
since 2013. In this study there are also efforts to analyze, record and interpret the current conditions related to human resource development through training.

Data analysis technique in this research uses Miles and Huberman model in (Sugiono, 2010) that is by Data Reduction, is the process of selecting, simplifying and concentrating attention on some information directly related to fish processing group, then Data Presentation combined and simplified some information obtained related Fish Processing Group in Sinjai District and then drew Conclusions.

\section{RESULTS AND DISCUSSION}

Basically, training in fish processing is one of the keys to the success of Fishery Office program. Moreover, after the holding of training for fish processing group to be able to produce a variety of products which already became the target of the Department. Related to this, in following the training there are requirements that must be prepared by the fish processing group. It is meant that the implementation of training can run well and the results The number of business groups in the Fishery Department that has been fostered amount of 52 groups. For more details can be seen in the list of attachments about the number of business groups under the guidance by the Department of Fishery in Sinjai District. While the type of product business can be seen in the following table:

Table: 1 Type of Fishery Products Business of Sinjai Regency

\begin{tabular}{|l|l|l|}
\hline Year & Types of Products Business & Amount \\
\hline 2013 & $\begin{array}{l}\text { Sea Cucumber drying, Fumigation, Shrimp Crackers, Fish } \\
\text { Drying, Marketing of Fresh Fish, Meatballs and Fish Floss }\end{array}$ & $\mathbf{7}$ \\
\hline 2014 & $\begin{array}{l}\text { Sea Cucumber Drying, Fumigation, Shrimp Crackers, Fish } \\
\text { Drying, Marketing Fresh Fish, Fish Meatball, Fish Floss, } \\
\text { Jelly and Stick Seaweed }\end{array}$ & $\mathbf{9}$ \\
\hline 2015 & $\begin{array}{l}\text { Sea Cucumber Drying, Fumigation, Shrimp Crackers, Fish } \\
\text { Drying, Marketing Fresh Fish, Fish Meatball, Abon Fish, } \\
\text { Jelly, Seaweed Stick, Grilled Fish Cake, Seaweed Crackers, } \\
\text { and Nugget. }\end{array}$ & $\mathbf{1 2}$ \\
\hline $\begin{array}{l}\text { Sea Cucumber Drying, Fumigation, Shrimp Crackers, Fish } \\
\text { Drying, Marketing Fresh Fish, Fish Meatball, Abon Fish, } \\
\text { Jelly, Seaweed Stick, Grilled Fish Cake, Seaweed Crackers, } \\
\text { and Nugget. }\end{array}$ & $\mathbf{1 2}$ \\
\hline Source: Processed from the data of the Department of Fishery 2016 & \\
\hline
\end{tabular}

The above data shows that there are variations of business types available, and the type of business always progressing from year to year. If seen table 1 above the type of business shows an increase from only 7 types of processing business in 2012 to 9 types of existing processing business, while in 2014 and 2015 types of fish processing has amounted to 12 types. 
Table 2: Sinjai Regency Fish Processing Data in 2017

\begin{tabular}{|l|l|l|l|}
\hline Group Name & Address & Processing Type & $\begin{array}{l}\text { Number of } \\
\text { Member }\end{array}$ \\
\hline Buhung Pitue & Sembilan Island & Fish Floss & 15 members \\
\hline Grup Tenggiri & Nort Sinjai & $\begin{array}{l}\text { Fish Meatball, Floss, } \\
\text { nugget, Fish,Grilled } \\
\text { Fish }\end{array}$ & 19 members \\
\hline Burung Camar & East Sinjai & $\begin{array}{l}\text { Fish Floss, Fish } \\
\text { Meatball }\end{array}$ & 13 members \\
\hline Sinar Bangko & East Sinjai & Fish Meatball & 25 members \\
\hline Sipakatuo & East Sinjai & Fumigation & 12 members \\
\hline Samataring Jaya & East Sinjai & Fumigation & 19 members \\
\hline Tulu Mario & East Sinjai & Fumigation & 10 members \\
\hline $\begin{array}{l}\text { Mutiara Laut Sinjai } \\
\text { Timur }\end{array}$ & East Sinjai & Fish Crackers & 20 members \\
\hline $\begin{array}{l}\text { Harapan baru Sinjai } \\
\text { Timur }\end{array}$ & East Sinjai & Fish Crackers & 15 members \\
\hline Source: Processed from the data of the Department of Fishery 2016 \\
\hline
\end{tabular}

The most common types of processors that followed the training were in groups other than fish meatballs and fumigation and the making of Fish Floss and grilled fish cake, followed by 10 people up to 25 people per group. The Tulu Mario group located in East Sinjai became the lowest group with frequencies of 10 members, while Sinar Bakko group was the highest group of 25 members. Each member of the business group can be determined by each group with the lowest record is 10 members.

\section{Implementation Process of Human Resources Development through Training} Implementation of human resource development activities in the fish processing

group through training conducted by the Department of Fishery is one form of strategy in improving the quality of business products owned by fish processing groups in Sinjai District. As the results of the interview said by the Head of Fishery Department as follows: "We at the Department of Fisheries are always trying to promote fisheries business owned by people in Sinjai District, one of which is the fish processing business, the activities we do is to conduct training and it also must be tailored to the Basic Tasks and functions on the field of business and institutional ". (Interview with the Fisheries Service on June 9, 2017).

The first way to be done by the Department of fisheriy in the development of fish processing group business is to collect data related to the existing business types in Sinjai District brought by fisheries instructor that is fish farming, fish drying and fish processing. Fishery Department always try to develop human resources especially fish processing group which always get training every year and Technical Guidance every month by fishery instructor or at least 3 months. However, in this implementation is still less than optimal in its application, because it must be supported with data from the fish processing group that must be accurate, and with the data, it will be a benchmark in determining the output of the processed products they produce every month.

In addition to training activities there is also Technical Guidance. Both things become one set in the development of human resources. Training is a series of activities undertaken by the Department of Fisheries with various methods of receiving materials directly by the trainees of each delegate of each group. While Technical Guidance is an activity that technically in the field done by experts who are competent in certain field of processing and fisheries extension 
directly to the fish processing group. Just Implementation of both activities is in turns, the first thing to be implemented is a training, if the training has been implemented then Technical Guidance will be implemented.

In order to determine the size of the need and define the topics they want to learn in more depth. This approach assumes that the prospective trainees that the fish processing group has the ability to analyze the results of the training process that followed. However, in the implementation that occurred in the field is not like that there. Implementation of the training did not conduct a survey in advance of the prospective trainees of the fish processing group. As a result of participating in the training the groups directly receive only the materials already prepared by the Fishery Department without specifying the topics that they will choose in depth. Thus, they are not given the opportunity to analyze the topics they need in analyzing the results of the training process they follow. Various reasons are the lack of choice of the various themes in the training in following the training without participation from the participants. Assessment of needs is a diagnosis to determine current problems and future challenges that must be met. Development of human resources through training can be known the problems and challenges faced by the fish processing group and how the future that must be faced by the Department of Fishery in empowering the group. One way that has been implemented is through training or Technical Guidance. Before the activity is carried out there should be a needs assessment. Needs assessment here is intended for the Department of Fisheries as the executor of the activity program capable of carrying out activities well or can run optimally. things that are targeted in the activity.

Meanwhile, to know the success of the purpose of holding the training for fish processing business group held by the Fishery Department in each year starting from 2013 until 2016 in detail can see the target and achievement per year obtained by the fish processing business group of Sinjai Regency. The data can be seen in the following table.

Table 3:

Objectives and Training Successes

\begin{tabular}{|c|l|l|l|l|}
\hline Year & \multicolumn{1}{|c|}{ Types of } & Training & Target \% & Achievements \% \\
\hline 2013 & $\begin{array}{l}\text { Training Fish } \\
\text { Meatball And Fish } \\
\text { Floss }\end{array}$ & $\begin{array}{l}\text { Objectives Knowledge } \\
\text { Upgrade and skills } \\
\text { processing group fishery } \\
\text { products }\end{array}$ & 50 & 35 \\
\hline 2014 & $\begin{array}{l}\text { Jelly dan Seaweed } \\
\text { Stick }\end{array}$ & $\begin{array}{l}\text { Knowledge Upgrade and } \\
\text { skills processing group } \\
\text { fishery products }\end{array}$ & 50 & 30 \\
\hline 2015 & Nugget & $\begin{array}{l}\text { Knowledge Upgrade and } \\
\text { skills processing group } \\
\text { fishery products }\end{array}$ & 50 & 40 \\
\hline 2016 & $\begin{array}{l}\text { Improvement of } \\
\text { Human Resources }\end{array}$ & $\begin{array}{l}\text { Quality improvement } \\
\text { Results Marketing of } \\
\text { fishery }\end{array}$ & 50 & 30 \\
\hline
\end{tabular}

Source: Data is processed from interview result and Data of Fishery Department 2017

From the results of the last 3 years Accountability Report shows that the workers in the field of processing and marketing of fishery products as many as 1,409 people with the largest contribution to the workers of retailers. 
From the table above can be seen the level of success and failure of training undertaken. Every year $50 \%$ but only $40 \%$ is realized the highest and the lowest $30 \%$. For more details, researchers can explain one by one due to not achieving the target of 50\% as follows: In 2013 only $35 \%$ achievement, this is due to the processing of fish and fish meatballs is the beginning of a processing consisting of only 2 groups. Both are still in the trial stage of fish products and still not too well known by the wider community, especially in Sinjai District. In addition, the quality of the products produced also still can not last long and the sense is still in the process which is fit for consumption. In the Year 2014 with $30 \%$ achievement of processed Jelly and stick seaweed, the realization has not reached the target because Sinjai District is a district that is not too much cultivation of seaweed in 2014 ago. So the managers are somewhat overwhelmed in finding basic materials; and the year 2015 with only $40 \%$ achievement that is Nugget, the realization has not reached the target although up $10 \%$ from the previous year. The obstacle here is the theme that makes the processing business group have to start over again about this new type of product, and must compete with the production of fish meat and Fish Floss that has existed since 2013. Thus, managers must be more active in marketing their products though.

In 2016 the realization of training actually decreased with the achievement of $30 \%$ which was already $40 \%$ in the Year 2015. The theme of this training is the Improvement of Marketing Quality of Fishery Products. After Department of Industry and Commerce performs a test of each processed product produced by each group of 6 types of preparations it can only reach the target of $30 \%$.

The constraints experienced until the targets are not achieved are due to the lack of available of processing facilities and infrastructure and the available of technical guidance and training are limited. In addition, the available of human resources are still limited to the experience undertaken in terms of the implementation of processing activities. Inadequate production management technology is also an obstacle in the process of enhancing the processed fishery products.

Achievement of targets to the current year by conducting trainings and good technical guidance on the processing group only with a target achievement of $30 \%$ with a target of $50 \%$ per year. Another factor that becomes an obstacle is that the human resources owned by the group is still very low, this is influenced by the level of education owned by the group also lace. That is only educated elementary and junior high school in general. This becomes one of the reasons of the Department of Fisheries to conduct human resources development of business actors as stated in the form of training activities. Development of human resources as a form of local government participation, especially Fishery Department of Sinjai District in providing a training to the group fish processing in order to get a coach. The form of coaching that is obtained by the processing group is training and Technical Guidance.

\section{CONCLUSION}

Based on the results of the discussion in the previous chapters, it can be concluded that in the process of implementation of human resources development group fish processing business by the Department of Fisheries in Sinjai has not run optimally. Various factors that become obstacles in the process of human resource development that is very limited time in training, the material given sometimes not in accordance with the wishes and needs of the group, the extension agent who is not responsible in carrying out the duties and functions in performing Technical Guidance on the business owned by the fish processing group, short duration of training activities are also often found in the fish processing group training; other than that the capital is less owned by some groups so it can not continue from what has been obtained from the training. The suggestions for the success of the development are (1) Additional training time is needed in presenting the material given so that the participants can 
better understand the material received: (2) The routine guidance by the fishery instructor in giving Technical Guidance to the fish processing group, effort can be empowered; (3) The material given should be in accordance with the needs of the fish processing group and based on the results of field observations.

\section{REFERENCES}

Ap Eiggenhuis, Rob van Dijk, 2007, High Performance Business Strategy, Inspiring Success Through Effective Human Resource Management, Kogan Page, London

Okoye, P.V.C. and Ezejiofor, Raymond A. . International Journal of Academic Research in Business and Social Sciences. October 2013, Vol. 3, No. 10.

Charles R Greer, 2001, Strategic Human Resource management, Prentice-Hall,Inc, New Jersey

Pawan S Budhwar and Yaw A Debrah, 2003, Human Resource management in Developing Countries, Routlege, London and New York

P.B. Beaumont, 1994, Human Resource Management, Key Concepts and Skills, SAGE Publications, London

Rahman, Nicole. Creighton Journal of Interdisciplinary Leadership Vol. 1, No. 2, November 2015 , pp. $120-129$

Rivai, Zainal Veithzal, 2005, Human R Resource Management for the Company, PT Raja Grafindo Persada, Jakarta

Sedarmayanti, 2016, Human Resource Management. Rafika Aditama, Bandung. Semardayanti, 2016, Restructuring and Organizational Empowermental to Cope with The Dynamc of Environmental Change, Masdar, Bandung

Susanti, Gita, 2015, Integrated Community Empowerment Policy Model: A Case Study of Implementation Network for Community Empowerment Policy of Fisherment in Coastal Area of South Sulawesi Province, Hasanuddin University, Makassar

Sugiono. 2010. Research Methods of Administration. Alfabeta. Bandung. Department of

Marine and Fishery of Sinjai Regency. 2013. http://dkp.sinjaikab.go.id/web/wp: content / uploads / 2014/05 / Statistics-Data Collection-2013.Pdf statistik Marine Fishery Sinjai

Regency (2009-2013).

Department of Marine and Fishery of Sinjai Regency. 2015.

http://sinjaiRegency.go.id/v2/index.php?option=com_content\&view=article\&id=1491:kegiat an-

2015-Departemen of Marine and Fishery \&catid=111\&Itemid=604. 